\title{
ŠIROKOPÁSMOVÝ PRÍSTUP V SLOVENSKEJ REPUBLIKE - NÁVRH OPATRENÍ NA ZABEZPEČENIE PRIMERANÉHO PRÍSTUPU ŠTÁTU NA PODPORU ROZVOJA ŠIROKOPÁSMOVÉHO PRÍSTUPU
}

\author{
Juraj Fabuš*
}

\section{Úvod}

Séria článkov vzniká za účelom vysvetlenia a objasnenia pojmu širokopásmový prístup, hlavnou témou tohto článku je identifikácia a návrh opatrení, ktoré napomôžu k rozšíreniu využívania širokopásmového prístupu pre všetkých obyvatel'ov SR. Jedná sa o posledný článok série.

Zverejnenie práce bolo z dôvodu obšírnosti problematiky rozdelené do viacerých článkov, ktoré boli postupne publikované $v$ tomto elektronickom časopise. V predchádzajúcich častiach boli vysvetlené základné pojmy z predmetnej oblasti, charakterizované jednotlivé služby, ako aj význam a výhody uplatnenia širokopásmového prístupu. Bol porovnaný stav v SR a EU. V tejto, poslednej časti, je návrh opatrení, ktoré napomôžu k rozšíreniu využívania širokopásmového prístupu pre všetkých obyvatel'ov SR.

Ciel'om je zvýšit' povedomie o širokopásmovom prístupe, zvýšit' záujem o jeho využívanie, čo bude mat' konečný vplyv aj na postavenie Slovenska v rámci EÚ, kde sme medzi členskými krajinami na poslednom mieste vo využívaní širokopásmového prístupu. Články sú určené všetkým, ktorí širokopásmové služby už využívajú, ale aj pre tých, ktorí sa s nimi ešte len zoznamujú.

\section{Podpora rozvoja širokopásmového prístupu}

Rozvoj širokopásmového prístupu je $\mathrm{v}$ Slovenskej republike pomerne nízky v porovnaní s inými krajinami. Existujú určité zvláštnosti, ktoré sú dané vel'kost'ou štátu a trhu, geografickými zvláštnost'ami, demografickým rozložením obyvatel'stva, rozvinutím trhu, pripravenost’ou populácie a pod., a ktoré majú výrazný vplyv aj na broadband.

Potenciálny trh pre broadband služby je na Slovensku pomerne malý. Slovensko, najmä jeho severná čast' je hornatá, preto prenosové trasy backbone sietí sú prakticky obmedzené na údolia riek. Štatistické údaje taktiež ukazujú na vel'ké digitálne rozdelenie pokial' ide o použivanie počítačov a Internetu medzi demografickými skupinami populácie, ale existujú aj určité rozdielnosti $\mathrm{v}$ územnom rozdelení, hlavne medzi mestskými a vidieckymi oblast'ami.

\footnotetext{
${ }^{*}$ Ing. Juraj Fabuš, PhD., Žilinská univerzita v Žiline, Fakulta prevádzky a ekonomiky dopravy a spojov, Katedra Spojov, Univerzitná 1, 01026 Žilina, Slovenská republika, tel.: +421 908171 890, E-mail:

juraj.fabus@fpedas.uniza.sk
} 
Podpora informačnej spoločnosti musí byt' a aj je vysokou prioritou pre štátne orgány SR. V roku 2003 bol napr. prijatý akčný plán Stratégia informatizácie spoločnosti v podmienkach SR, ktorý stanovuje postup a priority pri procese premeny spoločnosti na informačnú spoločnost'. V súvislosti so vstupom SR do Európskej únie je pre nás smerodajný program eEurope 2005, v ktorom je stanovené, že broadband prístup je vysokou prioritou pre Európsku úniu. Ako súčast' EÚ aj SR je nasmerovaná k implementácii a prijatí politiky a postupov pre povzbudzovanie využívania broadband prístupu a technológií.

Významný posun urobila Slovenská republika prijatím zákonov, ktoré sa priamo týkajú nového regulačného rámca Európskej únie. Je potešitel’né, že ako prvá z krajín, ktoré v roku 2004 rozšírili počet členov EÚ, vypracovala špecifikácie regulovaných rádiových rozhraní a spolu s Mad’arskom predbehla prijatím zákona o elektronických komunikáciách nielen všetky nové členské štáty, ale aj niektoré d’alšie krajiny EÚ. K dôležitým predpisom, ktoré sa týkajú oblasti IT bezpochyby patrí aj zákon o elektronickom obchode, ktorý má síce svoje nedostatky, vymedzuje ale významnú čast' základných pravidiel zodpovednostných vzt'ahov na internete.

V nasledujúcom texte uvádzam najdôležitejšie opatrenia na zlepšenie stavu v broadbandovom pripojení, ktoré zároveň pomôžu zvýšit' vyspelost' krajiny.

\section{Podporovat’ zavádzanie širokopásmových (broadband) technológií v cenách, ktoré budú dostupné pre všetkých občanov}

Hlavným problémom v súvislosti s nedostatkom broadbandových pripojení je cena, Slovensko totiž patrí medzi krajiny s najdrahším broadbandovým pripojením (spomedzi krajín EÚ). Dôraz sa musí klást' na spôsob ako sa priblížit' $\mathrm{k}$ ciel'u v broadband prístupe. Za žiadnych okolností by sa postup nemal odvodzovat' len od potreby, ale tiež od vízie zaistenia rovnakých príležitostí pre všetkých. Teda, tento celý problém by sa nemal zamerat' len na otázku či dopyt alebo ponuka je hlavným podnetom pre broadband prístup: broadband by mal byt' jednoducho k dispozícii, pretože je to základ pre rozvoj krajiny a pre pokrok spoločnosti ako celku. Každý by sa mal podiel'at' na úsilí: vláda, občania a tiež súkromný sektor.

Zníženie ceny pripojenia a súvisiacich služieb je jednoznačne cesta vedúca $\mathrm{k}$ podstatnému oživeniu záujmu o slovenský broadband, o čom svedčia aj mnohé ankety, výsledkom ktorých bola cena broadbandového pripojenia hlavným dôvodom nevyužívania broadbandových technológií. Rozvoj vhodných broadband infraštruktúr prístupných všetkým občanom za prijatel'né ceny, môže účinne prekonat' nebezpečenstvo zväčšovania digitálneho rozdelenia občanov alebo regiónov a zabezpečit' rovnaké príležitosti a možnosti pre rozvoj miestnych skupín.

\section{Poskytovanie priamej podpory zo strany štátu}

Z hl'adiska čo najmenšieho zásahu štátu do konkurenčného prostredia je nevyhnutné poskytnút' priamu podporu verejného sektora len pre také oblasti, pre ktoré nie sú možné komerčné riešenia, teda pre oblasti najmenej atraktívne a zaostalé.

Štát môže poskytovat' príspevok pre občanov, ktorí by chceli využívat’ širokopásmový internet. Príspevok by sa dával jednorazovo, a týkal by sa sumy súvisiacej s inštaláciu prípojky, pretože prvotná suma za pripojenie ku širokopásmového Internetu je podstatnou 
čast’ou nákladov na pripojenie. Jedným z riešení zvýšenia využívania širokopásmového prístupu je aj poskytovanie určitého ,skúšobného“ broadband pripojenia k internetu zadarmo - na určitú dobu.

Štát poskytuje priamu podporu, ktorá sa týka najmä:

- širokopásmového prístupu pre verejný sektor budovaním metropolitných optických sietí, najmä pre menej rozvinuté regióny,

- vybudovanie širokopásmového prístupu k budovám, skupinám budov podmienkou je spoluúčast' použivatel'ov,

- pri spracovaní a spolufinancovaní investičných akcií z fondov EÚ.[1]

\section{Rozširovat' ponuku služieb a zvyšovat' ich dostupnost' využitím existujúcich sietí, a ich postupné budovanie}

Štát by sa mal snažit' vytvárat' neustále nové projekty na všetkých úrovniach, pre vytvorenie všetkých nových aplikácií - teda e-služieb, ktoré budú pokrývat' skutočné potreby jednotlivých občanov SR.

Všetky takéto služby treba dostatočne propagovat', taktiež pre ne vyčleňovat' príslušné finančné prostriedky.

Vybudovat' vo verejných knižniciach a na mestských úradoch verejne prístupné internetové pracoviská, umožňujúce slobodný a lacný prístup $k$ informáciám pre všetkých občanov

Zaostalé vidiecke oblasti a hlavne malé obce môžu zriadit' na mestskom úrade, resp. v knižnici, jednu počítačovú miestnost' so širokopásmovým internetom, kde by mali občania príslušnej obce možnost' prístupu k internetu, a tak využívat' služby, ktoré ponúka.

Obec by takúto aktivitu mohla využívat' s podporou finančných prostriedkov z eurofondov. Starší občania a deti do 15 rokov budú internet využívat' zadarmo, ostatní za určitý symbolický poplatok. Takto by sa mnohí, aj starší občania, s broadbandom oboznámili, pričom by sa zvýšila aj vzdelanostná úroveň obyvatel'stva.

Taktiež školské multimediálne učebne sa môžu (napr. dva krát do týždňa) otvorit’ aj pre verejnost', čo by bolo podnetom pre využívanie širokopásmového internetu aj občanmi, ktorí by inak ku nemu nemali prístup.

\section{Zvýšit' povedomie občanov SR o broadbande}

Štát musí zabezpečit' kvalitné informácie o širokopásmovom prístupe, vykonávat' rôzne prednášky a distribuovat' informačné materiály s obsahom, ktorý dostatočne objasňuje výhody plynúce z využívania širokopásmového prístupu, taktiež dokonalé vysvetlenie všetkých broadbandových služieb, ako aj prínosy pre potencionálnych používatel'ov. Občania dostatočne nechápu pojem broadband, a často krát si pod týmto pojmom predstavujú len samotný prístup $k$ internetu.

Mnohé e-služby, ako e-vzdelávanie, ale aj e-commerce, sú vel'mi populárne, a aj ked' sa v poslednej dobe využívajú čoraz viac, stále ešte existuje segment l'udí, ktorí takéto služby nevyužíva. Rozvoj elektronického obchodu a podnikania predstavuje jednu z dôležitých 
podmienok zachovania a zvyšovania konkurencieschopnosti ekonomiky a jej schopnosti podiel'at' sa na medzinárodnej del'be práce. Elektronický obchod výrazne ovplyvní budúce obchodné vzt'ahy.

Tiež e-government je mimoriadne aktuálnou výzvou pre nové členské štáty EÚ. Väčšina verejných služieb, ktoré doteraz vykonával štát prechádza na samosprávu miest a obcí a samosprávu regiónov. To všetko vedie nielen k zvýšeniu efektívnosti a rýchlosti služieb pre občanov a zníženiu nákladov, ale najmä k zvýrazneniu transparentnosti verejnej správy a k rozšíreniu možností občanov priamo mat' informácie a priamo participovat' na rozhodovacom procese. Teda aj $\mathrm{v}$ tomto smere je potrebná dostatočná informovanost' občanov, aby takéto služby využívalo čo najviac občanov.

\section{Podpora a zvýhodňovanie využívania WiFi na miestach, kde nie je možné budovat' pevnú infraštruktúru pre širokopásmový prístup}

Pripojenie pomocou WiFi je na Slovensku počtom unikátne, čo logicky vyplýva z geografického členenia územia SR. Často krát je to jediný spôsob ku širokopásmovému prístupu najmä pre malé obce v odl'ahlých oblastiach.

Štát by mal poskytovat' príspevky pre domácnosti, ktoré by chceli WiFi pripojenie, ale iba v tých oblastiach, kde nie je možné využívat' inú technológiu.

Nedostatok internetových prípojok však nie je jediným problémom, ale taktiež je to i nízka rýchlost' pripojenia. Telekomunikačné firmy často do vidieckych lokalít neumiestňujú potrebnú techniku na poskytovanie širokého pásma, pretože sa im to neoplatí. Štát preto musí práve pre takéto oblasti zabezpečit' čo najväčšie finančné zvýhodnenia.

\section{Dostatočné využitie prostriedkov z eurofondov}

Na Slovensku je v súčasnej dobe rozbehnutý program Informatizácia spoločnosti, ktorého jedným z ciel'ov je aj to, aby mal každý občan prístup k širokopásmovému pripojeniu do internetu.

Ministerstvo financií SR chce finančnú pomoc smerovat' do najmenej rozvinutých oblastí, ktoré oblasti sú ale tie vyvolené, sa ešte nevie. Až 2300 obcí s celkovo 1,6 milióna obyvatel'ov nepôsobí ani jeden provider ponúkajúci rýchle online pripojenie (stav k 28. 5. 2008). Najviac takýchto miest je v Prešovskom, Košickom a Nitrianskom kraji. Okresy s najhoršou dostupnost'ou širokopásmového prístupu technológiou DSL sú Trebišov, Stará Lubovňa, Sobrance, Zlaté Moravce, Vel'ký Krtíš.

Európska únia poskytne celkovo až 113 miliónov eur, paradoxom ale je, že problémom nie sú peniaze, ale skôr to, nakol'ko budú samosprávy kompetentné, aby zvládli napísat' kvalitné projekty a manažovat' administratívne náročné procesy, čo býva v mnohých prípadoch dôvodom neúspešnosti, ale tiež samosprávy odrádza aj samotný zdíhavý proces.

Aj z tohto dôvodu by mali byt' zriad'ované určité pomocné inštitúcie, ktoré by samosprávam pomáhali hlavne s náročnou administratívou v rámci projektov. Inštitúcie by mali byt' samozrejme nezávislé a štát by mal zabezpečit', aby mali hlavne malé samosprávy možnost' využívat' služby takýchto inštitúcií. 
Za protitrhové, ohrozujúce hospodársku sút’až a $\mathrm{v}$ rozpore $\mathrm{s}$ ochranou investícií definovanou legislatívou EÚ, možno považovat' projekty podpory budovania širokopásmovej infraštruktúry $\mathrm{v}$ regiónoch SR, $\mathrm{v}$ ktorých súkromný sektor už obdobnú infraštruktúru vybudoval, resp. plánuje v strednodobom horizonte vybudovat'.

Ako dobrý príklad efektívneho čerpania a použitia finančnej pomoci práve z EÚ slúži Írsko, kde Komisia schválila štátnu pomoc v rámci ustanovení Zmluvy o ES na preklenutie digitálnej priepasti, čiže odsúhlasila Regionálny širokopásmový program - MAN, ktorého ciel'om je podpora vybudovania otvorenej vel'kej neutrálnej infraštruktúry (kruhy optických vlákien), na účely poskytovania komunikačných služieb v 120 írskych mestách, kde nie je takáto infraštruktúra dostupná. Na tento účel sa odhadla maximálna výška verejných prostriedkov 170 mil. EUR a budú použité aj finančné prostriedky zo štrukturálnych fondov EÚ.

Ďalším príkladom, kedy Európska komisia schválila čerpanie štátnej pomoci sú krajiny Grécko a Litva. Finančné prostriedky boli určené na zmenšenie širokopásmovej komunikačnej medzery, s ciel'om zvýšenia penetrácie voblastiach a regiónoch, kde je širokopásmový internet málo prístupný a rozšírený.

Pokial’ preskúmame zámery a vyhlásenia Európskej únie a orgánov, ktoré poskytujú pomoc a finančné prostriedky pri stavbách optických sietí, tak odhalíme, že sú naozaj zamerané na rozvoj v oblastiach, kde sa nenachádzajú žiadni významní, alebo vôbec žiadni telekomunikační operátori. Pri financovaní projektov je potrebné dodržat' zásady Európskej komisie a to technologickú neutralitu, nenarušenie hospodárskej sút’aže a zabezpečenie otvoreného prístupu poskytovatel'ov služieb k novovybudovanej infraštruktúre.

Dostupnost' internetu $\mathrm{v}$ menej atraktívnych lokalitách sa teda nezlepší bez istých dodatočných stimulov. Fondy EÚ zohrávajú životne dôležitú úlohu pri odstraňovaní markantných digitálnych rozdielov medzi mestami a vidiekom.

\section{Záver}

Nedostatok širokopásmových pripojení úzko súvisí s nákladmi na vybudovanie prístupových sietí, ktoré sa budujú na Slovensku vel'mi t’ažkopádne a skôr je tendencia ich budovat' $\mathrm{z}$ komerčnej sféry. Komerčná sféra je (a $\mathrm{v}$ súlade $\mathrm{s}$ prioritami EÚ i má zostat') kl'účovým hráčom na telekomunikačnom trhu. Je preto žiaduce (okrem iného i z dôvodu ochrany investícií) podporovat' rozvoj telekomunikačnej infraštruktúry výhradne $\mathrm{v}$ tých častiach SR, v ktorých by takéto investície v strednodobom časovom horizonte nerealizoval súkromný sektor.

Dôležité pri budovaní informačnej spoločnosti je, aby všetky verejné zdroje ako aj prostriedky z fondov EÚ boli použité do takej miery, že internet a jeho služby už nebudú neprebádanou oblast'ou pre vel'kú čast' našich obyvatel'ov. Ide o to, aby sa zvýšila prístupnost' k širokopásmovému internetu, vytvorili sa podmienky pre efektívnu elektronizáciu verejnej správy a rozvoj elektronických služieb.

\section{Je preto nutné:}

- neustále pokračovat' $\mathrm{v}$ liberalizácii telekomunikačného trhu a to najmä skvalitnením procesu regulácie tohto trhu, 
- podporit' vybudovanie prístupu na širokopásmový internet a jeho rozšírenie v menej rozvinutých oblastiach, na základe Národnej stratégie pre širokopásmový prístup,

- podporit' programy založené na partnerstve so súkromnou sférou, ktorých ciel'om je zabezpečit' počítače so širokopásmovým pripojením na internet pre širokú verejnost'.

\section{Literatúra}

[1] Národná stratégia pre širokopásmový prístup. 2005. Dostupné na:

$<$ http://www.telecom.gov.sk/index/index.php?ids=3891>

[2] Národná rada SR. Zákon o elektronických komunikáciách. 2003. [online]. TÚ SR, 2003. Dostupné na: <http://www.teleoff.gov.sk/ sk/zakon.html>

[3] Stratégia informatizácie spoločnosti v podmienkach SR a Akčný plán. Dostupné na: $<$ http://www.elet.sk/brt/ egovernment/ vlastnymat.rtf>

\section{Grantová podpora}

Článok je súčast'ou riešenia úlohy Zvýšenie atraktívnosti vysokej školy prostredníctvom marketingovej komunikácie vzdelávacej inštitúcie - KEGA 3/5030/07. 